\title{
Variation in the Quality of Treated Wastewater by Local Sand Filter: The Case of the Algerian Sahara Sand
}

\section{Kendouci MA ${ }^{1,2^{*}}$, Kharroubi $\mathbf{B}^{1}$, Maazouzi $\mathbf{A}^{1,2}$ and Bendida $\mathbf{A}^{1,2}$}

${ }^{1}$ Department of Hydraulic, University of Science and Technology, Oran-Mohamed Boudiaf B.P. 1505 El-M'Naouer 31000 Oran, Algeria

${ }^{2}$ Department of Civil Engineering and Hydraulic, University of Bechar, Bechar, Algeria

"Corresponding author: Kendouci MA, Department of Hydraulic, University of Science and Technology, Oran-Mohamed Boudiaf B.P. 1505 El-M'Naouer 31000 Oran, Algeria, Tel: +213790594126; E-mail: aminekendouci@gmail.com

Rec date: Apr 12, 2016; Acc date: May 13, 2016; Pub date: May 20, 2016

Copyright: (C) 2016 Kendouci MA, et al. This is an open-access article distributed under the terms of the Creative Commons Attribution License, which permits unrestricted use, distribution, and reproduction in any medium, provided the original author and source are credited.

\begin{abstract}
In urban areas, population growth generates significant amounts of wastewater that is treated in sewage treatment plants specialize or reject directly controlling interest in the natural environment. Many scientists are looking into the issue to try to find solutions to clean water and make it drinkable.

We are interested in the technique of sand filtration (in the region southwest of Algeria), as an essential phase for the treatment of wastewater, such methods are known to be well suited to rural areas, since they have a good quality of treatment, a relatively simple operation and low maintenance.

The method is based on the following principle: a slow filtration, water passes under a constant hydraulic load ( 30 $\mathrm{cm}$ water) the filter bed (60 $\mathrm{cm}$ of sand), the hydraulic load is kept constant during the experiment.

A physicochemical analysis is performed on the water sample before and after filtration, the filter bed to give us a discount of around $50 \%$ in the levels of contaminant parameters such as NTK, Ammonium, Nitrate, and Nitrite. The reduction of $B O D, C O D$ and suspended solids is about $90 \%$. It was observed a significant increase in the potassium from $33.19 \mathrm{mg} / \mathrm{l}$ to $99.89 \mathrm{mg} / \mathrm{l}$.
\end{abstract}

Keywords: Sand dune (Western Erg) Algeria; Wastewater; Filter bed; Permeability; Treatment; Physicochemical analysis

\section{Introduction}

The great Western Erg is in the northwest of the Sahara $600 \mathrm{~km}$ south of the Mediterranean, along $500 \mathrm{~km}$ WSW off the 150 to $200 \mathrm{~km}$ ENE and covers an area of nearly $100,000 \mathrm{~km}^{2}$ [1]. Granulometric and mineralogical studies of these soft sediments will select sandy sites economic interest. These ranges known to Ergs sands provide a landscape that characterizes the Sahara and that gives it a particular site, and to value this type of unique landscape, the media coverage of these sites is a great contribution to the economy region.

The Sahara sand dunes extend over large areas and seem to be an obstacle in the development of urban infrastructure Saharan and an ecological barrier called desertification. The study of these sandy sites also presents a cartographic impact; therefore prospecting bedrock is difficult to study [1].

The Ergs hide ground water, reservoirs of oil, gas and even extensions of heel high economic interest, thus mapping and sampling hidden by sand give additional geo-economic data. The study of its large areas is to support scientifically to identify the economic potential that these sites can offer and hide (Figure 1).

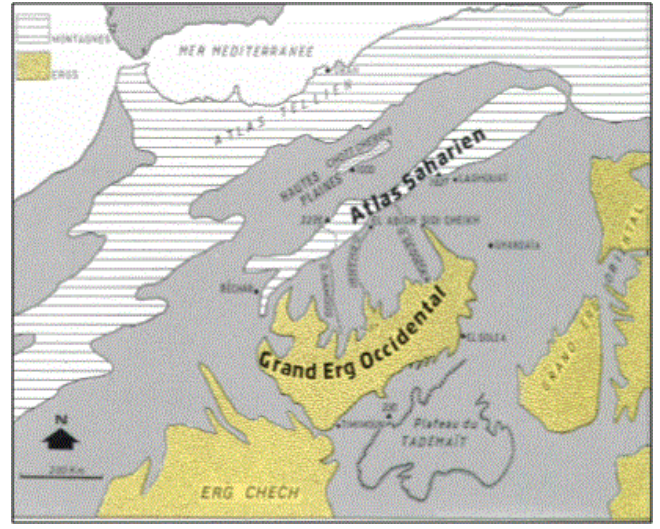

Figure 1: Localization of the Western Erg.

\section{Materials and Methods}

\section{Experimental}

Figure 2 shows the experimental setup used for the testing of filtration. The driver is constituted by a glass column of $5 \mathrm{~cm}$ diameter and $100 \mathrm{~cm}$ tall and cylindrical. The effective height of the filter bed and $60 \mathrm{~cm}, 30 \mathrm{~cm}$ is used for the filtered water which is maintained 
Citation: Kendouci MA, Kharroubi B, Maazouzi A, Bendida A (2016) Variation in the Quality of Treated Wastewater by Local Sand Filter: The Case of the Algerian Sahara Sand. Hydrol Current Res 7: 247. doi:10.4172/2157-7587.1000247

Page 2 of 5

constant throughout the experiment in order to keep the hydraulic load on the same filter bed of sand [2] (Table 1).

According to the study of the hydrodynamic porous medium we have obtained a flow rate of $0.95 \times 10^{-6} \mathrm{~m}^{3} / \mathrm{s}$ and permeability which is recorded in the order of $7.26 \times 10^{-4} \mathrm{~m} / \mathrm{s}$.

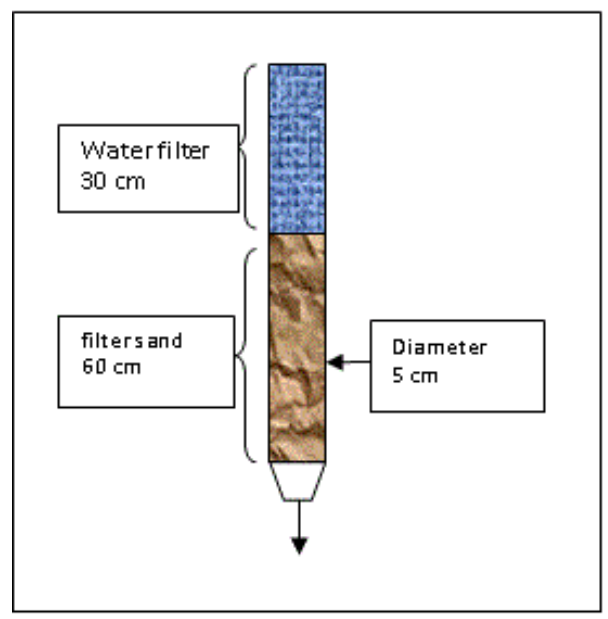

Figure 2: Schematic illustration of the experimental apparatus.

\begin{tabular}{|c|c|}
\hline Parameters & Type of device \\
\hline $\mathrm{pH}$, salinity and conductivity & $\begin{array}{l}\text { Conductivity consort } 861 \text {; multi parameter } \\
\text { WTW } 197\end{array}$ \\
\hline Ammonium & $\begin{array}{l}\text { Helios Y spectrophotometer UV type UV } \\
\text { visible }\end{array}$ \\
\hline Sodium and potassium & $\begin{array}{l}\text { flame spectrophotometer JENWA clinco } \\
\text { LPFP7 }\end{array}$ \\
\hline Sulfates & $\begin{array}{l}\text { Helios Y spectrophotometer UV type UV } \\
\text { visible }\end{array}$ \\
\hline Nitrate-Nitrite & AL800 spectrometer \\
\hline COD & Eco thermo reactor VELP scientific \\
\hline
\end{tabular}

Table 1: Equipment used.

The physical parameters measured include: $\mathrm{pH}$, salinity and conductivity. Chemical parameters determined are sulfate, chloride, nitrate, nitrite, ammonium, COD, BOD using standard techniques of analysis. Assay methods used are as follows:

(Consort 861)

$\mathrm{pH}$, salinity, TDS and conductivity, potentiometric method

- The Kjeldahl nitrogen mineralization after AFNOR T 90-110

- Spectrophotometry was used for the determination of sulfates;

- Colorimetry for determining the content, nitrates and nitrates.

\section{Results and Discussion}

The type of sand studied belongs to the category fine sand is well supported by its low porosity $42 \%$; the usual values of porosity for soils vary between $30-60 \%$, it more or less fine sand can also be quantified by the effective diameter $\mathrm{d} 10$ is of the order of $0.17 \mathrm{~mm}$. The fineness modulus (FM) 2.16 for sand; and their very low permeability which is on the order of $7.26 \times 10-4 \mathrm{~ms}-1$, the uniformity coefficient is less than 2 we can conclude that the sand has a uniform particle size (Figure 3 and Table 2).

\begin{tabular}{|l|l|}
\hline Paramètre & Sable \\
\hline Fineness modulus (FM) & 2.16 \\
\hline Effective diameter d10 (mm) & 0.17 \\
\hline Coefficient of uniformity $(\mathrm{CU})$ & 1.76 \\
\hline Surface area of the material $\mathrm{cm}^{-1}(\mathrm{As})$ & 36.6 \\
\hline Density $\left(\mathrm{kg} / \mathrm{m}^{3}\right)$ & 2.63 \\
\hline Porosity $(\varepsilon) \%$ & 42.01 \\
\hline Permeability $\alpha(\mathrm{m} / \mathrm{s}) 10^{-4}$ & 7,26 \\
\hline
\end{tabular}

Table 2: Physical characteristics of sand.

Chemical analysis performed on the sand provides us with qualitative and quantitative information on the chemical composition of the filter bed. The results obtained indicate that sand does not contain manganese, the presence of oxides of iron and aluminum may be an indicator of the presence of these elements in different forms.

Calcium oxide has significant concentrations in the sand reaches $1.15 \%$ and very probably due to the presence of calcite $\left(\mathrm{CaCO}_{3}\right)$ recognized as soluble and can condition the presence of $\mathrm{Ca}^{+2}$, the present iron oxide a concentration of $0.18 \%$ [2].

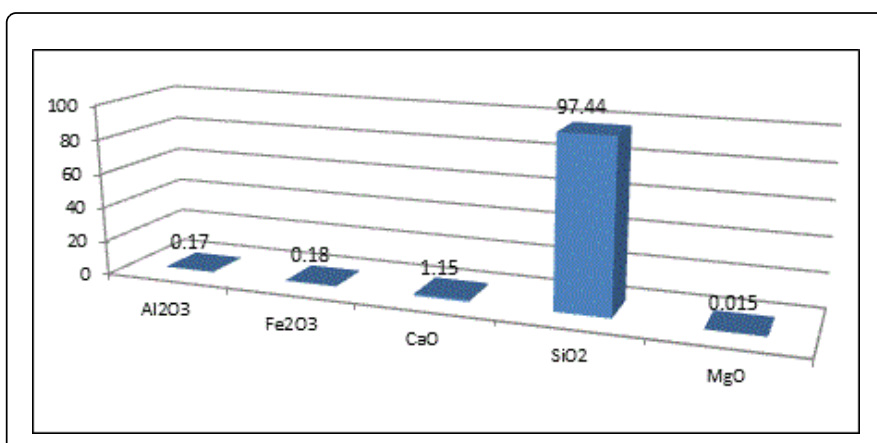

Figure 3: Chemical composition of Sand.

\section{Conductivity, salinity, $\mathrm{pH}$ and dissolved oxygen}

The conductivity, salinity, $\mathrm{pH}$ and dissolved oxygen in the waste water before filtration is $3930 \mu \mathrm{S} / \mathrm{cm}, 1.97 \mathrm{~g} / \mathrm{l}, 8.14$ and $0.11 \mathrm{mg} / \mathrm{l}$ respectively, and showing relatively high values.

Conductivity, $\mathrm{pH}$ and salinity of the three columns during the experiment are moderately stable, conductivity ranges from 3930 $\mu \mathrm{S} / \mathrm{cm}$ to $3320 \mu \mathrm{S} / \mathrm{cm}$ and the salinity of $1.98 \mathrm{~g} / \mathrm{l}$ to $1.71 \mathrm{~g} / \mathrm{l}$. Regarding the treated water, the $\mathrm{pH}$ is always less than that stored in the input reaches a maximum $\mathrm{pH}$ of 8.07 is a parameter influencing both the level of activity, the growth of bacteria and the solubility of the compounds it is important to control, especially as the bacteria are sensitive to the variation (Figure 4) [3]. 
For the dissolved oxygen values indicate a fluctuation of from 0.11 $\mathrm{mg} / \mathrm{l}$ to $6.9 \mathrm{mg} / \mathrm{l}$ for the treated water. From the graph the recorded contents dissolved $\mathrm{O}_{2}$ at the outlet are considerably greater than those of the entry, which is the good aeration to water level of the aeration tank, the need to grow aerobic microorganisms ensuring the oxidation of organic matter, which leads to a good biological waste water treatment. The low dissolved $\mathrm{O}_{2}$ recorded at the entrance characterizing arrival wastewater rich in organic matter and dissolved inorganic and disruption of air exchange at the interface due to the presence of fats, detergents [4].

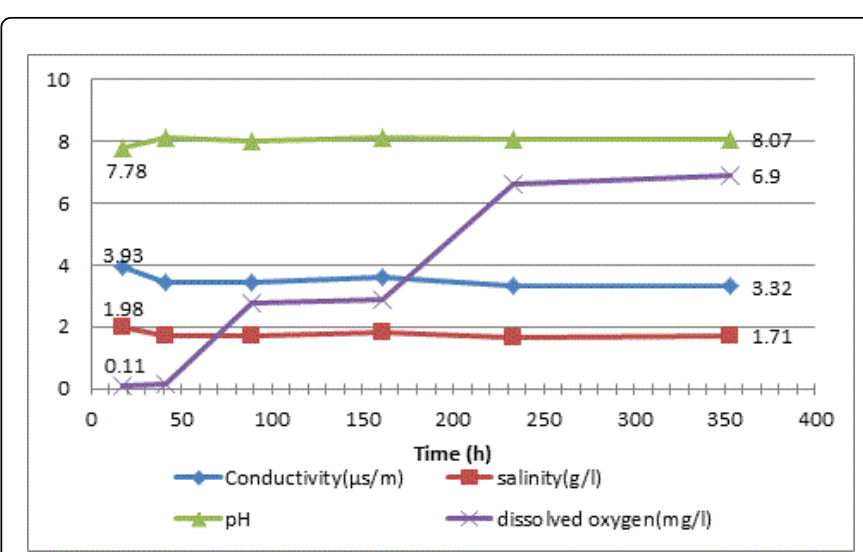

Figure 4: Change in conductivity, salinity, $\mathrm{pH}$ and dissolved $\mathrm{O}_{2}$ for treated water.

\section{BOD, COD and suspended solids (SS)}

The values of BOD, COD and SS in the waste water before filtration is $150 \mathrm{mg} / \mathrm{l}, 215 \mathrm{mg} / \mathrm{l}$ and $156 \mathrm{mg} / \mathrm{l}$, respectively.

From the results shown in Figure 5 a reduction of $90 \%$ was observed for all three parameters (BOD, COD and TSS) in the column, the residence time factor is very important in achieving the abatement rate; all parameters were monitored for a sharp decline in the filtration phase with time, apart from the soluble COD. Regarding TSS, this effect was expected by virtue of the filter function, and for COD, this is due to the physic-chemical reactions. It is then found that particulate and colloidal elements will be drawn from the settling. Filtration entry, COD will be mostly in soluble form [5].

The solids removal is considerable. From the first time filtration, SS are retained for $76 \%$ to $81 \%$. This rate increases to $87-94 \%$ at the end of the process. These high yields allow the system to produce high quality water for regards MES [6]. Water collected at the end of treatment meet the discharge standard of wastewater into the environment (50 $\mathrm{mg} / \mathrm{l})[2,6]$.

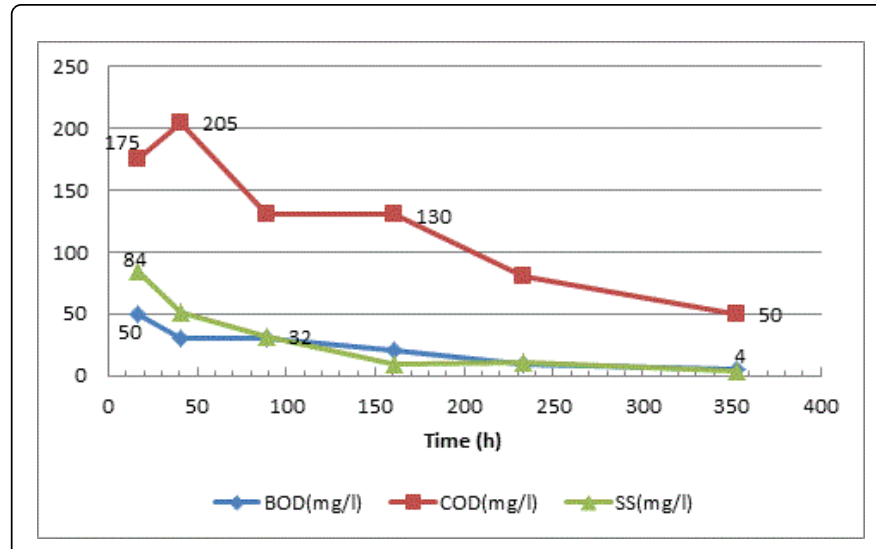

Figure 5: Variation of BOD, COD and SS for treated water.

\section{Sulfate and chloride}

The chloride and sulfate contents of the waste water before filtration were $795.76 \mathrm{mg} / \mathrm{l}$ and $923 \mathrm{mg} / \mathrm{l}$ respectively. Sulfates and chlorides present in very high concentrations, these levels may be due most likely is because the releases are urban nature the use of detergents based sulfites that it transforms (oxidation) sulfate (Figure 6).

Chloride concentration undergoes a decrease in $923 \mathrm{mg} / \mathrm{l}$ to 781 $\mathrm{mg} / \mathrm{l}$ for the treated water, the reduction of the content of $\mathrm{SO}_{4}{ }^{-2}$ as a function of time is $51 \%$.

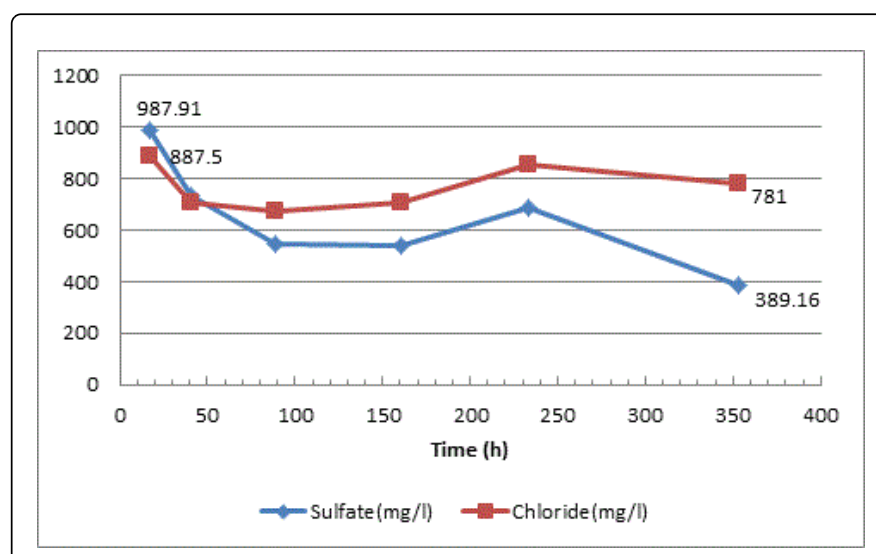

Figure 6: Variation of chloride and sulfate for treated water.

\section{The Kjeldahl nitrogen (TNK), ammonium, nitrate and nitrite}

Urine is the main indicator of the presence of nitrogen in the urban waste water, and a detergent ammonium base, the reactions can take place ammonification transforming this organic ammonium $\mathrm{NH}_{4}{ }^{+}$ nitrogen (reduced form of the nitrogen), in fact the oxygen demand by the ammonium is very high they are molecules (nitrogen compound) originally fragrant odor [7-10]. The maximum value of the nitrate is $7.94 \mathrm{mg} / \mathrm{l}$. Kjeldahl Nitrogen has alarming concentrations are observed in the maximum release $62.18 \mathrm{mg} / \mathrm{l}$, the values of ammonium and nitrites are respectively $0.6 \mathrm{mg} / \mathrm{l}, 26.60 \mathrm{mg} / \mathrm{l}$ (Figure 7).

The nitrite content of wastewater examined record a variation with time of filtration, these levels vary between $0.6 \mathrm{mg} / \mathrm{l}$ and $0.3 \mathrm{mg} / \mathrm{l}$, 
Page 4 of 5

which may be due to leaching of nitrite or other nitrogen compounds which can undergo a nitrification by soil microorganisms or those of water, or oxidized by the oxygen present in the soil or dissolved in water [11-13].

The analysis results show that nitrate filtration their contents vary between $2.71 \mathrm{mg} / \mathrm{l}$ and $1.72 \mathrm{mg} / \mathrm{l}$. The decrease in the content of nitrate was observed probably because of the phenomena of transformation and consumption by microorganisms.

There is a decrease in the content TNK, Ammonium Nitrate, Nitrite in the column as a function of time, the elimination of NTK $59 \%$ rate; the removal rate of 55\% ammonium [14-18].

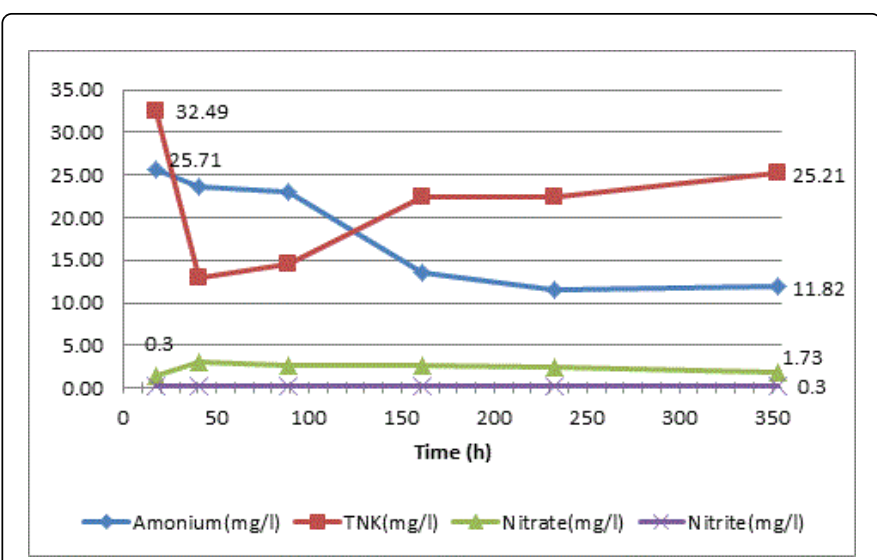

Figure 7: Changes in TNK, Ammonium, Nitrate and Nitrite for treated water.

\section{Sodium and potassium}

Values of Sodium, Potassium for wastewater before filtration were $27.12 \mathrm{mg} / \mathrm{l}$ and $33.19 \mathrm{mg} / \mathrm{l}$ respectively. The sodium content evolves over time, reaching a maximum rate of $21.87 \mathrm{mg} / \mathrm{l}$; this decrease is probably due to adsorption phenomena. The analysis results show that the potassium levels increase their $33.19 \mathrm{mg} / \mathrm{l}$ to $99.89 \mathrm{mg} / \mathrm{l}$. From the results shown in Figure 8, the sodium content of the column for 14 days is moderately stable $[19,20]$.

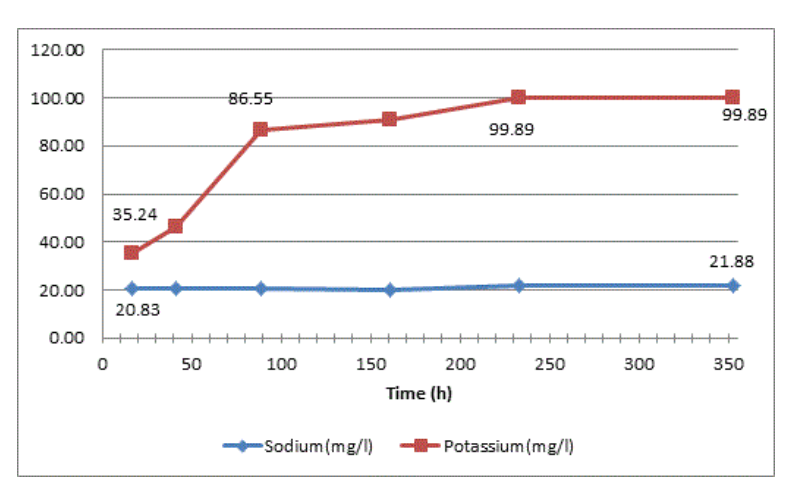

Figure 8: Variation of Sodium and Potassium for treated water.

\section{Conclusion}

It is clear from this work in the laboratory scale, the sand has studied favorable to their use as filter bed features, we can say that it is a ground textures sandy an effective diameter (d10) of $0.17 \mathrm{~mm}$ and a uniformity coefficient $(\mathrm{Cu})$ of 1.76 .

Chemical analysis performed on the sand provides us with qualitative and quantitative information on the chemical composition of the filter bed. The results obtained indicate that the mineral quartz is the most represented considered insoluble portion in the sand $97 \%$.

According to the study of the hydrodynamic filter bed of sand we found a speed of $9.5 \times 10^{-4} \mathrm{l} / \mathrm{s}$, the flow is more or less in the same order of grandeur in the sand filters.

The filter bed gives us a remarkable reduction in the levels of contaminant parameters such as NTK, Ammonium, Nitrate, Nitrite, $\mathrm{BOD}, \mathrm{COD}$ and suspended solids. If we take the content of nitrite is obtained a $50 \%$ decrease. We also observed a significant increase in the potassium content after passing of $33.19 \mathrm{mg} / \mathrm{l}$ to $99.89 \mathrm{mg} / \mathrm{l}$. The reduction of suspended solids (SS), chemical oxygen demand (COD) and biochemical oxygen demand (BOD) is around 90\%, with better allowance.

The filtration process on sand, their specified lies in the simplicity of implementation and management. The availability of the material used as filter bed and simplicity of implementation and management are benefits that we were moved to make this study.

The filtration process shows that the materials used in this work have significant potential in terms of treatment of domestic wastewater. However, the yields are still improvable purification, particularly as regards the disinfection. A continuation of tests with different experimental protocols should enable the production of treated water quality compliance with both standards discharge to the WHO recommendation on agriculture without restriction. This requires the installation of a more elaborate experimental station and / or the establishment of a small pilot plant.

\section{Acknowledgements}

The authors would like to express their gratitude to the MESRS of Algeria, for the support.

\section{References}

1. Yann C (1991) History of massive dunes, the Great Western Erg (Algeria). Geodynamics of continental environments, Sécheresse, p: 2.

2. Kendouci MA (2012) Development of local materials for wastewater pretreatment. Magister Thesis, University of Bechar, Algeria.

3. Franck R (2002) Water analysis, regulatory and technical aspects. Scérén CRDP AQUITAINE Edition. Bordeaux, pp: 165-239.

4. Hazourli S, Boudiba L, Ziati M (2007) Characterization of wastewater pollution of the industrial area of Al-Hajar, Annaba. LARHYSS Journal 6: 45-55.

5. Goula BTA, Kouame IK, Coulibaly L, Gnagne T, Savane I, et al. (2007) Characterization of waste-activated sludge of a food plant for use as irrigation water lawns in the humid tropics. Rev Sci Water 20: 299-307.

6. Rodier J (2005) The analysis of natural water, wastewater, water mer. 8th edn. Technical DUNOD, Paris, pp: 1008-1043.

7. Koller E (2004) Treatment of industrial pollution. Water air waste soil sludge. Prais Dunod, p: 424.

8. Afnor (1986) French Association for Standardization. Water test methods. 2nd edn. Collection of French standards, Paris, France. 
Citation: Kendouci MA, Kharroubi B, Maazouzi A, Bendida A (2016) Variation in the Quality of Treated Wastewater by Local Sand Filter: The Case of the Algerian Sahara Sand. Hydrol Current Res 7: 247. doi:10.4172/2157-7587.1000247

Page 5 of 5

9. Afnor (1994) French Association for Standardization. Collection of French standards: water quality. Environment, Paris, France.

10. Ardois C, Collin JM, Roujou C (2002) Characterization of Aeolian sand Chernobyl used for sorption studies. Technical Note IRSN / DPRE / SERGD No. 02-72.

11. Degremont (1978) Technical water Memento. 8th edn, France.

12. Elouazzani D (2005) Physicochemical characterization and optimization in building and construction of ash from the incineration of paper mill sludge. PhD Thesis, Institute of Applied Sciences, Lyon.

13. Kellil A, Bensafia D (2003) Phosphate removal by direct filtration sand bed. Rev Sci Water 16: 317-332.

14. Kjeldsen P, Barlaz MA, Rooker AP, Baun A, Ledin A, et al. (2002) Present and long-term composition of MSW landfill leachate. A review Crit Rev Env SCI Tec 32: 297-336.

15. Maazouzi A, Kettab A, Badri A, Zahraoui B, Khelfaoui R (2014) Algerian Sahara Sand Dunes Characterization. Silicon Springer 6: 149-154.
16. Marle CM (2006) Henry Darcy and fluid flows in porous media. Oil Gas Sci Technol Rev IFP 61: 599-609.

17. Kendouci MA, Kharroubi B, Khelfaoui R, Bendida A, Dennai B, et al. (2013) Simulation of water filtration in porous zone based on Darcy's law. Energy Procedia 36: 163-168.

18. Kendouci MA, Kharroubi B, Maazouzi A, Bendida A (2013) Study of physic-chemical quality of wastewater discharged into the natural environment the case of Bechar River Algeria. Energy Procedia 36: 287-292.

19. Rooklidge SJ, Erick RB, Bolte JP (2005) Modeling antimicrobial contaminant removal in slow sand filtration. Water Res 39:331-339.

20. Wanko A, Mose R, Lienard A (2005) Processing capabilities of a synthetic effluent infiltration percolation. Rev Sci Water 18: 165-175. 